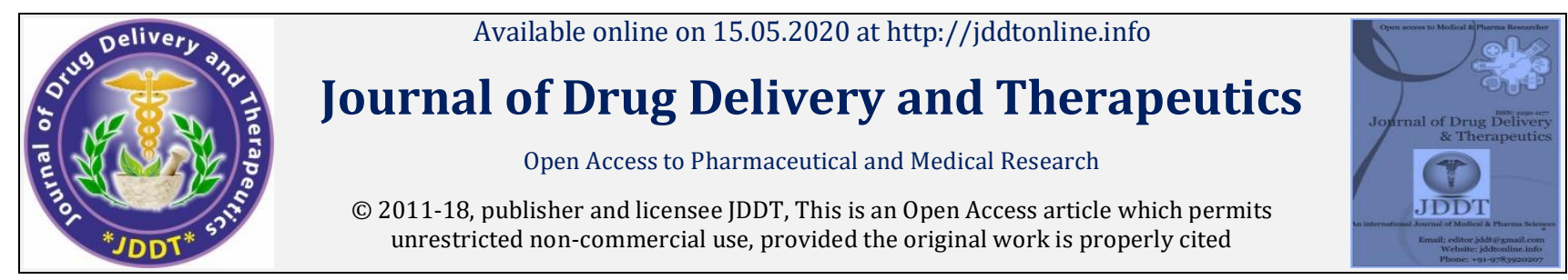

Open $\odot$ Access

Review Article

\title{
A Review on Epilepsy and its Management
}

\author{
V.V. Potnis, Ketan G. Albhar, Pritamsinh A. Nanaware*, Vishal S. Pote
}

Department of Pharmaceutics, JSPM’S JSCOPR, Hadapsar, Pune, INDIA, 411028

\begin{abstract}
Today, people face various types of stress in everyday fast life and most people in the world suffer from various neurological disorder. Epilepsy is one of the most common neurological disorders of the brain, affecting about 50 million people around the world, and $90 \%$ of them are coming from developing countries. Genetic factors and brain infection, stroke, tumors and epilepsy cause high fever. It imposes a great economic burden on the health systems of countries associated with stigma and discrimination against the patient and also his family in the community, in the workplace, school and home. Many patients with epilepsy suffer from severe emotional stress, behavioral disorders and extreme social isolation. There are many different types of seizure and mechanisms by which the brain generates seizures. The two features of generating seizures are hyperexcitability of neurons and a hyper synchronousneural circuits. A variety of mechanisms alters the balance between excitation and inhibition in predisposing brain local or generalized hyperexcitability region and a hypersynchronia. Purpose of the review is to discuss the history, epidemiology, etiology, pathophysiology, classification of epilepsy, symtomps, diagnosis, management of epilepsy and future trends.
\end{abstract}

Keywords: Anti-epileptic drugs, pathophysiology, seizures, epidemiology, hypersynchrony

Article Info: Received 27 Feb 2020; Review Completed 21 April 2020; Accepted 29 April 2020; Available online 15 May 2020

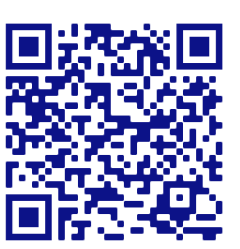

Cite this article as:

Potnis VV, Albhar KG, Nanaware PA, Pote VS, A Review on Epilepsy and its Management, Journal of Drug Delivery and Therapeutics. 2020; 10(3):273-279 http://dx.doi.org/10.22270/jddt.v10i3.4090

*Address for Correspondence:

Mr. Pritamsinh A. Nanaware, Department of Pharmaceutics, Jayawantrao Sawant College Of Pharmacy \& Research, Hadapsar, Pune, Maharashtra, India 411028,

\section{Introduction}

Up to $1 \%$ of the population is affected by epilepsy, making it the second most common neurological disease after a stroke.(1) About 50 million people worldwide have epilepsy, and $90 \%$ of them come from developing countries.(2) The perception of epilepsy has improved in several respects in recent years. It is a common chronic neurological disease in which the balance between brain excitability and inhibition inclines uncontrolled excitability and is characterized by recurrent unprovoked epileptic seizures. $(3,4,5)$ Now there is clear evidence that there are clear differences in pathophysiology between immature and mature brains and the effects of strokes. It is a collection of different forms of epileptic seizures, which vary widely in frequency, appearance, cause and management of consequences.(6) Seizures are associated with the characteristic signs and / or symptoms of abnormal neuronal activity, excessive or synchronous in the brain.(7) Epileptic seizures frequently cause a temporary loss of consciousness, leave the patient at risk of physical harm and often interfere with education and employment. Epilepsy is more likely to occur in young children or people over 65 years of age; however, it can occur at any time. Epilepsy is not a single disease, but a syndrome with very divergent symptoms, involving episodic ISSN: 2250-1177 abnormal electrical activity in the brain.(8) All epileptic syndromes are not for life, some forms are confined to particular stages of childhood. Conventional treatment of epilepsy consists mainly of anticonvulsant drugs.(9) However, more than $30 \%$ of people with epilepsy do not have crisis control even with the best drugs available. $(10,11)$ Although these drugs often control or reduce the frequency of seizures, some patients show little or no improvement and, therefore, surgery can be considered in difficult cases. Symptomatic therapy is available because drugs inhibit seizures, but no prophylaxis or effective cures are available. Compliance with medications is a big problem due to longterm therapy with the undesirable effects of many medications.(12) The purpose of this overview is to provide general considerations and treatment of epilepsy.

\section{History of epilepsy}

The word epilepsy comes from the Greek 'epilepsia' that means 'to seize', which in turn has merged into the form 'epi' meaning above and Means 'lambanein' which they assume.(13) ancient times epilepsy was related to weak religions or always controlled by a demon. In the past, epilepsy, many people believed that epilepsy affected people, to some extent, took on demons or that visions experienced 
by epileptics considered sacred disease in support of this vision was sent to you by the gods. Even among the Hmong animist generations, for example, epilepsy was regarded as an attack by a demonic spirit, but the person concerned could be revered as a shaman through explicit experiences. It can be defined in most cultures people who have epilepsy have been despised and even remained confined to jail; at the windlass, the birthplace of modern neurology, JeanMartin Charcot noted that epileptics nothing but mental retardation, as suffering from chronic syphilis or criminal lunatics. As with other parts of Africa, Tanzania, even today people believed that epilepsy is connected with evil spirits, witch craft or poisoning or being contagious.(14) The Romans believed that epilepsy was sent curse God and was known as Morbus comitialis (disease of the assembly hall). Even today the stigma continues, but people understand that they are progressively reduced with time, for the least developed countries. Hippocrates said that it will not take long to eradicate the threat of epilepsy, because it is not divine.(15)

\section{Epidemiology}

Epilepsy is one of the most serious common neurological disorders.(16) It is estimated that there are 55 missing people with epilepsy in India, 20 in the US missing and 3 missing in the UK.(17) Every year, 120 per 100,000 people in the United States come to medical treatment due to a recently recognized seizure. At least $8 \%$ of the general population will have at least one seizure and do not have epilepsy. The recurrence rate of an unprovoked first crisis in 5 years ranged from $23 \%$ to $80 \%$. The age-adjusted incidence of epilepsy is 44 per 100,000 people per year. Every year there are about 125,000 new cases of epilepsy; of these, $30 \%$ are in people under 18 at the time of diagnosis. The relatively high frequency of epilepsy in the elderly now be recognized. At least $10 \%$ of patients in long-term care centers who are taking at least one antiepileptic drug (AED).(6) National Sentinel Audit of epilepsy-related deaths led by 'Bereaved epilepsy' drew attention to this important issue. The check revealed; "1,000 deaths occur annually in the UK due to epilepsy" and most of them are associated with seizures and $42 \%$ of deaths were potentially avoidable.(18)

\section{Causes of epilepsy}

The cause of epilepsy is completely unknown. The word epilepsy does not indicate anything about the cause or severity of seizures in person, some cases of epilepsy are induced by genetic factors, but can also result in brain injuries caused by blows to the head, strokes, infections, high fever or tumors.(19) It has been noted that heredity (genetics) plays an important role in many causes of epilepsy in very young children, but they can be a factor for people of any age. In cases, not all people who have severe head trauma (a clear cause of epileptic seizures) will develop epilepsy.(7) Some epileptic syndromes referred to as epileptic reflex precipitating specific needs or triggers seizures such as reading, intermittent and precipitating lights such as emotional stress, sleep sleep thermal stress deprivation, alcohol and febrile illness are examples of precipitating factors cited by patients with epilepsy. In particular, the influence of various provoking factors varies with epilepsy syndrome.(20) The menstrual cycle in women with epilepsy can affect the patterns of relapse seizure, catamenial seizure epilepsy related to the menstrual cycle.(21) There are several causes of epilepsy are common to different age groups;

1. In the neonatal and early childhood period, most common causes are hypoxic-ischemic encephalopathy, infections of the central nervous system, trauma, congenital abnormalities of the central nervous system and metabolic disorder.

2. At the end of the first and second childhood, febrile convulsions most common infections can be caused by trauma and central nervous system.

3. Epileptic syndromes have been observed in the child hood in general.

4. In adolescence and adult Bell causes are more likely to be secondary to any lesions to the central nervous system

5. In the elderly, cerebrovascular disease is the most common cause, other causes, including CNS tumors, head trauma and other degenerative diseases such as dementia.(22)

\section{Pathophysiology of epilepsy}

Seizures are paroxysmal appearances of the cerebral cortex. A seizure happens when a sudden lopsidedness happens between the excitatory and inhibitory strengths with the cortical neuron organize. The fundamental physiology of a convulsive scene is identified in an unsteady cell film or encompassing back / adjoining cells. seizure root in gray matter of any cortical or subcortical zone. Initially, a small number of neurons focus abnormally. normal membrane conductance and decomposition of inhibitory synaptic current and excessive diffusion excitability at the local level to produce a focal or more generally attack for the production of a generalized attack. This house is transmitted through physiological pathways to involve areas adjacent to remote areas. As conductance potassium abnormality, a defect in voltage-dependent ion channels, or a deficiency of membrane ATPases associated with ion transport can cause unstable neuronal membrane and trigger an attack. Some neurotransmitters (e.g., glutamate, aspartate, acetylcholine, norepinephrine, histamine, corticotropin releasing factor, purines, peptides, cytokines, and steroid hormones) to enhance the excitability and the propagation of neuronal activity, while the butyric acid-amino (GABA) and dopamine inhibit neuronal activity and propagation.During a seizure, the demand for increased blood flow to the brain to bring CO2 and bring substrate for metabolic activity of neurons, as the seizure is prolonged, the brain suffers more ischemia which can result in neuronal destruction and brain damage.(6) Mutations in different genes may be related to certain types of epilepsy. Genes encoding protein subunits of ion channels sensitive to activated voltage ligands have been associated with generalized epilepsy and seizure syndromes in childhood.(23) Hypothesized a mechanism for some forms of hereditary epilepsy is mutation of genes encoding sodium channel proteins; these channels remain open long defective sodium and causing neurons to be hyper excitable as glutamate, an excitatory neurotransmitter released in large quantities can form neurons towards the neuron glutamanergicas adhere close-triggers.(16) 


\section{Seizures}

Table 1: International classification of epileptic seizures $(24,25)$

\begin{tabular}{|c|c|}
\hline Types & Description \\
\hline $\begin{array}{l}\text { I. Partial Seizures } \\
\text { (seizures begin locally) }\end{array}$ & $\begin{array}{l}\text { A. Simple (without impairment of } \\
\text { consciousness) } \\
\text { 1. with motor symptoms. } \\
\text { 2. with special sensory or soma to sensory symptoms. } \\
\text { 3. with psychic symptoms } \\
\text { B. Complex (with impairment of consciousness) } \\
\text { 1. Simple partial onset followed by impairment of consciousness with or without } \\
\text { automatisms. } \\
\text { 2. Impaired consciousness at onset with or without automatisms. } \\
\text { C. Secondarily Generalized (partial onset evolving to generalized tonic } \\
\text { clonic seizures) }\end{array}$ \\
\hline $\begin{array}{l}\text { II. Generalized seizures } \\
\text { (bilaterally symmetrical } \\
\text { and without local onset) }\end{array}$ & \\
\hline III. Unclassified Seizures & \\
\hline IV. Status epileptics & \\
\hline
\end{tabular}

The different types of seizures are given in Table 1 and here is the brief description of the seizures.

\section{Partial seizures}

In simple partial seizures (focal cortical epilepsy) the seizure focus in the context motor gives such attacks provoke used seizures consisting of a particular muscle group. Patients lose voluntary control of the affected parts of the body, without losing consciousness. In the complex partial seizure, the discharge begins locally, and often remains localized. Symptoms include involuntary muscle contractions, abnormal sensory experiences or autonomic secretion, or effects on mood and behavior, often called psychomotor epilepsy. (26) The focus of sequestration in the temporal lobe. secondary generalized attack, immediately preceding a partial attack of a generalized tonic-clonic seizures (grandmal).

\section{Generalized seizures}

Generalized seizures contain the entire brain, consisting of the reticular system, for this reason producing atypical electrical undertaking in both hemispheres. instant loss of recognition is characteristic of generalized epileptic seizures.(27) absence seizures (petitmal) is common in children associated with momentary loss of consciousness, but without muscle components or shaking small bilateral (from flickering eyelid to a wider movement of clonic body.(28) In general, characterized by means of 3 to 30 seconds of unconsciousness or lowered recognition.(29) Myoclonic are epileptic seizures in which the motor manifestation is myoclonus. Clonics are characterized by loss of consciousness, autonomic symptoms and clonic rhythmic characters of all muscles. tonic convulsions are associated with loss of consciousness and autonomic symptoms accompanied by Tonic contractions of the limbs.(30) Tonicclonic seizure (grandmal) consists of a sharp initial contraction of the muscles of the whole body causing a tonic spasm. Stops breathing and defecation, urination and salivation often occurs this tonic phase lasts a minute and is followed by a series of violent and synchronous convulsions.(27) The patient remains unconscious for several minutes, and then gradually recovered, feeling unwell and confused. Atonic (akinetic) seizures associated with loss of consciousness with relaxation of all muscles due to excessive inhibitory shock, the patient may fall.(30) Infantile Spasm (hypsarythmia) intermittent muscle spasms associated with deterioration and progressive mind.

\section{Unclassified category}

A third category includes unclassified undetermined epilepsy and epileptic syndromes. Special syndromes include conditions such as febrile convulsions in which seizures are related to specific situations. Approximately $2-4 \%$ of children experience disorders associated with a tissue disease. Only 2 and $3 \%$ of these children become epileptic in recent years. This is a six-fold increase in risk compared to the general population. Several factors are associated with an increased risk of developing pre-existing neurological disorder or developmental delay, family history of febrile convulsions or complicated epilepsy. For children at high risk of developing recurrent febrile convulsions and epilepsy, diazepam administered rectally at the time of fever can prevent recurrent seizures and avoid side effects of chronic therapy.(12)

\section{Status epilepticus}

Epileptic status can be defined as a prolonged seizure, or a period of repeated seizures with restoration of normal consciousness in the middle, lasting more than 30 minutes, 
although prolonged and repeated seizure activity lasting more than 5 to 10 minutes may weight epileptic status and requires treatment. Any type of seizure can lead to epileptic status, but generalized clonic tonic epileptic status is the most common and dangerous type. The initial treatment is to help breathing and to maintain blood pressure. Then antiepileptic treatment can be stated with diazepam I.V. or rectal solution followed by phenytoin (or alternatively phenobarbital clomethearate or paraldehyde) to prevent relapses. Once the seizure is controlled, sodium phenytoin can be administered I.V. with monitoring of blood pressure and ECG. If the measures do not control seizures, administer anesthetics, such as short-acting barbiturates, such as thiopental, and should be discharged to the patient. Children may have behaviors similar to epileptic seizures, but they are not caused by epilepsy.

These include:

1. The watchful eye.

2. Benign Tremors (children under 2 years, usually when they are tired or excited).

3. Behavior of self-gratification (nodding, swaying, banging the head).

4. Conversion disorder (shaking and shaking of the head). Conversion disorder can be distinguished from epilepsy, because episodes do not occur during sleep and do not involve incontinence or self-harm.

\section{Symptoms of seizure}

The Seizure is the indication event in epilepsy associated with episodic high frequency discharge pulse from a group of neurons in the brain. Clinical signs and symptoms of seizure depend on the location of epileptic discharges in the cortex and the extent and pattern of the spread of epileptic discharge in the brain. for example, the share of convulsions causes motor cortex, hypothalamus causes peripheral autonomic discharge and participation of the reticular formation of the upper cerebral cords to loss of consciousness.(27)

\section{Diagnosis}

They have developed several tests to determine epilepsy in an individual and its type.

EEG Monitoring: Electron encephalogram is very useful in the diagnosis of various seizure disorders. EEG may be normal in some patients who still have the clinical diagnosis of epilepsy even many people who do not have epilepsy show some unusual brain activity in the video monitoring EEG is often used in combination with EEG to determine the nature of a person's seizures.

Brain Scan: It is an important diagnostic tool that is useful for identifying brain tumors, cysts and other structural abnormalities in the brain. Brain scans are commonly used include CT (computed tomography), PET (positron emission tomography) and MRI (magnetic resonance imaging) SPECT (single photon emission computed tomography), MRS (magnetic resonance spectroscopy). CT scan and MRI reveal the structure of the brain. Positron emission tomography and magnetic resonance imaging can be used to monitor the activity of brain abnormalities. SPECT is used to detect seizure foci in the brain. MEG (magneto encephalogram) detects magnetic signals generated by neurons. MRS can detect abnormalities in the biochemical processes of the brain.

\section{Medical History}

Medical history, including the symptoms and duration of seizures helps determine the epilepsy and type of seizures present in the person.

\section{Blood Tests}

Seizures are occasionally caused by acute toxic or stressful metabolic disorders, in which case appropriate therapy should be directed to specific abnormalities, for example, hypocalcemia. Blood samples are often screened for genetic or metabolic diseases that may be associated with seizures. Blood samples are analyzed to detect problems such as infections, lead poisoning, anemia and diabetes that can cause or trigger seizure.(31)

\section{Management of Epilepsy}

Anticonvulsant and antiepileptic terms are used interchangeably. An anticonvulsant is an agent that blocks experimentally induced seizures in laboratory animals and antiepileptic is a drug used in medicine for control epilepsies.(32)

\section{Principles of management}

1. Any factor that causes epilepsy should be treated, for example, brain neoplasm.

2. Patients should be instructed about the disease, the duration of treatment and the need for compliance.

3. Precipitating should avoid provoking factors, such as alcohol, sleep deprivation, emotional stress.

4. Natural variation should be anticipated, for example, especially attacks may occur or only around menstruation in women.

5. The antiepileptic should be administered only if the type of seizure and the frequency necessary, that is, more than one adjustment every 6-12 months.(33)

The antiepileptic drugs have been classified as follows in Table 2and Table 3 and the important pharmacokinetic parameters are tabulated below (Table 4): 
Table 2: Classification of drugs used in the therapy of epilepsies (34)

\begin{tabular}{|c|c|c|}
\hline Seizure type & $\begin{array}{l}\text { Conventional } \\
\text { anti-seizure drug }\end{array}$ & $\begin{array}{l}\text { Recently developed } \\
\text { anti-seizure drug }\end{array}$ \\
\hline $\begin{array}{l}\text { I. Partial seizures } \\
\text { (i) Simple partial }\end{array}$ & $\begin{array}{l}\text { Carbamazepine } \\
\text { Phenytoin } \\
\text { Phenobarbital } \\
\text { Primidone } \\
\text { Valproate }\end{array}$ & $\begin{array}{l}\text { Gabapentin } \\
\text { Lamotrigine }\end{array}$ \\
\hline (ii) Complex partial & $\begin{array}{l}\text { Carbamazepine } \\
\text { Phenobarbital } \\
\text { Phenytoin } \\
\text { Primidone } \\
\text { Valproate }\end{array}$ & $\begin{array}{l}\text { Gabapentin } \\
\text { Lamotrigine }\end{array}$ \\
\hline $\begin{array}{l}\text { (iii) Partial with } \\
\text { secondly generalized } \\
\text { tonic clonic seizure }\end{array}$ & $\begin{array}{l}\text { Carbamazepine } \\
\text { Phenobarbital } \\
\text { Phenytoin } \\
\text { Primidone } \\
\text { Valproate }\end{array}$ & $\begin{array}{l}\text { Gabapentin } \\
\text { Lamotrigine }\end{array}$ \\
\hline $\begin{array}{l}\text { II. Generalized seizure } \\
\text { I)Absence Seizures }\end{array}$ & $\begin{array}{l}\text { Clonazepam } \\
\text { Ethosuximide } \\
\text { Valproate }\end{array}$ & \\
\hline $\begin{array}{l}\text { (ii) Myoclonic Seizure } \\
\text { (iii) Tonic-clonic Seizure }\end{array}$ & $\begin{array}{l}\text { Valproate } \\
\text { Carbamazepine } \\
\text { Phenobarbital } \\
\text { Phenytoin } \\
\text { Primidone } \\
\text { Valproate }\end{array}$ & \\
\hline
\end{tabular}

Table 3: Chemical classification of antiepileptic drug(28)

\begin{tabular}{|l|l|l|}
\hline SR.NO & Chemical Class & Examples of antiepileptic drug \\
\hline 1 & Barbiturates & $\begin{array}{l}\text { Phenobarbitone, Mephobarbitone, } \\
\text { Primidone }\end{array}$ \\
\hline 2 & Hydantoins & Phonations, Mephenytoin \\
\hline 3 & Iminostilbene & Carbamazepine \\
\hline 4 & Oxazolidinedione & Trimethadione (Troxidone) \\
\hline 5 & Succinimide & Ethosuximide \\
\hline 6 & Aliphatic Carboxylic acid & Valproic acid (Sodium valproate) \\
\hline 7 & Benzodiazepines & Clonazepam, Diazepam \\
\hline 8 & Acetyl urea & Phenacemide \\
\hline 9 & Newer drugs & $\begin{array}{l}\text { Progabide, Vigabatrin, Gabapentin Lamotrigine, Felbamate, Topiramate, } \\
\text { Tiagabine }\end{array}$ \\
\hline 10 & Miscellaneous & Acetazolamide, Dexamphetamine \\
\hline
\end{tabular}


Table 4: Pharmacokinetics of commonly used antiepileptic drugs(27)

\begin{tabular}{|l|l|l|l|l|l|l|l|}
\hline Sr.No & Drug & $\begin{array}{l}\text { Tmax } \\
\mathbf{h})\end{array}$ & $\begin{array}{l}\text { Protein } \\
\mathbf{b i n d i n g} \\
\mathbf{( \% )}\end{array}$ & $\begin{array}{l}\mathbf{t} \mathbf{1} / \mathbf{2} \\
\mathbf{( h )}\end{array}$ & $\begin{array}{l}\text { Therapeutic } \\
\mathbf{l e v e l}(\boldsymbol{\mu g} / \mathbf{m l})\end{array}$ & $\begin{array}{l}\text { Active } \\
\text { metabolites }\end{array}$ & $\begin{array}{l}\text { Major inactive } \\
\text { metabolites }\end{array}$ \\
\hline 1 & Phenobarbitone & $1-6$ & 48 & 96 & 15.25 & None & $\begin{array}{l}\text { P-hydroxy } \\
\text { Phenobarbitone }\end{array}$ \\
\hline 2 & Carbamazepine & $6-12$ & 75 & 18.7 & $4-12$ & $10,11-$ Epoxite & $\begin{array}{l}10,11- \\
\text { transdihydroxy } \\
\text { derivative }\end{array}$ \\
\hline 3 & Sodium Valproate & $0.5-4$ & 90 & $7-12$ & $50-100$ & ---- & $\begin{array}{l}\text { Oxidative } \\
\text { derivatives }\end{array}$ \\
\hline 4 & Phenytoin & $4-12$ & 92 & $9-140$ & $10-20$ & None & $\begin{array}{l}\text { P-Hydroxy } \\
\text { phenytoin }\end{array}$ \\
\hline 5 & Primidone & $0.5-9$ & 15 & 15.6 & $4-12$ & Phenobabit-ones & $\begin{array}{l}\text { P-hydroxy } \\
\text { phenobarbitone }\end{array}$ \\
\hline 6 & Clonazepam & $1-3$ & 82 & 30 & $0.15-0.3$ & 3-hydroxyclonazepam & $\begin{array}{l}\text { 7-amino- } \\
\text { clonazepam }\end{array}$ \\
\hline 7 & Ethosuccimide & $1-2$ & Neglible & 60 & $50-100$ & None & Hydroxyderivatives \\
\hline
\end{tabular}

Note: $T$ max indicates time to reach peak serum level after oral dose, $\mathrm{Vd}$ is apparent volume of distribution, $\mathrm{t}$ max signifies elimination half-life of $\max 1 / 2$ drugs.

\section{Mechanism of action of antiepileptic drugs}

Antiepileptic drugs may act mainly by one of three main mechanisms:

(i) To reduce the excitability of the electrical cell membranes, in particular (block) dependent voltage sodium channels that are responsible for the inward current that generates an action potential;

(ii) Strengthen synaptic inhibition, GABA-mediated, by inhibiting GABA transaminase or drugs with properties of agonist GABA direct; the result is an increase in the permeability of the membrane of the chloride ion, which reduces the excitability cell;

(iii) Calcium channel inhibiting T-type (the important convulsion control), or inhibit excitatory neurotransmitters. For example, glutamate. $(27,33)$ Some common contraindications are as follows:

\section{Epilepsy and oral contraceptives}

Some antiepileptic drugs (carbamazepine, phenytoin, barbiturates, topiramate, oxcarbazepine) induce steroid metabolizing enzymes and may cause hormonal contraception fails. Therefore, taking antiepileptic drugs require a higher dose of oral contraceptive containing estrogen (50mg / day).(33)

\section{Pregnancy and epilepsy}

Management of epilepsy during pregnancy can present problems for both the mother and the fetus. The incidence of miscarriage and still birth is increased in women with epilepsy. Therefore, patients should have their inves gate convulsive disorders properly and treated before pregnancy with the lowest dose of the developing fetus, due to the possibility of anoxium and metabolic disorder. Minor seizures are probably harmless and therefore do not need to eradicate; it should advise patients to take folic acid and vitamin K orally. Since some antiepileric affect the metabolism of folic acid and folic acid is a risk factor for neural tube defects via. liver enzymes inducing antiepileptic drugs reduce the concentration of the mother of vitamin $\mathrm{K}$, which can aggravate any postpartum bleeding.(33)

\section{Breast feeding}

Antiepileptics are usually distributed in breast milk in concentration and breastfeeding is considered safe when administered in normal doses, with the exception of barbiturates and ethosuccimide. Neonatal sedation problems can occur with benzodiazepines and barbiturates and ethosuccimide is distributed in significant quantities in human milk and therefore lactation should be avoided.(30)

\section{Epilepsy in children}

Adjustments in children are treated as in adults, but children can respond differently and irritable, because for example with sodium valproate or phenobarbital. If there were febrile convulsions, a drug used for epilepsy most can be administered continuously (for example phenobarbitone 3-4 $\mathrm{mg} / \mathrm{kg} /$ day) until the child is 5 years old. But prolonged medication for example phenytoin or phenobarbital can interfere with cognitive development, the drug is withdrawn.(33)

\section{Conclusion}

Therefore, the choice of an anticonvulsant agent is based primarily on its effectiveness for specific types of epileptic seizures and epilepsy. Although crisis control is generally good in most patients, the percentages of patients with epilepsy suffer from intractable or drug-resistant epilepsy, despite the early and optimal daily treatment adequate anticonvulsant agent. Therefore, there is a need for new drugs with greater benefit in relation to side effects and tolerability, including at the expense of effectiveness in comparison with existing antiepileptic agents. Although there are many treatments available, it is engaging very dedicated to innovative approaches. Many of these approaches focus one lucidating genetic cellular and molecular mechanism of hyperexcitability, ideas that promise to provide specific goals for novel therapy. 


\section{References}

1. Carl E S. Epilepsy: a review of selected clinical syndromes and advances in basic science. Journal of Cerebral Blood Flow \&Metabolism 2006; 26:983-04.

2. Epilepsy: aetiogy (Sic), epidemiology and prognosis, World Health organization. 2001; Achieved form the original on 2007-05-18. Available at:

http://web.archieve.org/web/20070518073641/http://www. who.int/mediacentre/facsheets/fs165/en/Retrieved 2007-0614.

3.Commission on Epidemiology and prognosis. International League Against Epilepsy. Guidelines for epidemiologic studies on epilepsy. Epilepsia 1993; 34(4):592-96.

4. Blume W, Luders H, Mizrahi E, Tassinary C, Van Emde Boas W, Enjel J. Glossary of descriptive terminology for ictal semiology; report of the ILAE taskforce on classification and terminology. Epilepsia 2001; 42(9):1212-18.

5.Gregory L H, Yehezkiel Ben-A. The Neurobiology and Consequences of Epilepsy in the Developing Brain. Pediatric Research2001; 49(3):320-25.

6. Gidal BE, Garnett WR. Epilepsy. In: Dipiro J T, Talbert RL, Yee GC Matzke GR, Wells BG, Posey LM, eds. Pharmacotherapy: a pathophysiologic approach. USA: McGraw-Hill Companies Inc, 6th ed. 2005:1023-46.

7. Fisher RS, Van Emde B, Blume W et al. Epileptic seizures and epilepsy: definition proposed by the International League Against Epilepsy (ILAE) and the International Bureau for Epilepsy (IBE). Epilepsia 2005; 46(4):470-72.

8. Epilepsy: A Manual for Physicians. Word Health Organization. New Delhi: Regional Office for South-East Asia, 2004:1

9.The National Society for Epilepsy. what is epilepsy? 2009 Available at: http: //www.epilepsynse.org.kk/ about epilepsy/what is epilepsy (Accessed on 15 February 2009)

10.Cascino GD. Epilepsy: contemporary perspectives on evaluation and treatment. Mayo Clinic Proceedings 1994; 69:1199-11.

11.Engel J. Jr. Surgery for seizures. New England Journal of Medicine1996; 334(10): 647-652. Available at: doi: 10, 1056/NEJM199603073341008.PMID 8592530.

12. McNamara J O. Drugs effective in the therapy of the epilepsies. In: Hardman JG, Limbird LE, Goodman Gilman A, 10th ed. Goodman and Gilman's the pharmacological basis of therapeutics. NewYork: McGraw-Hill Companies Inc, 2001: 52148.

13. Oxford English Dictionary. Retrieved 8 September 2009.

14. Jilek-Aall L. Morbus Sacer in Africa; some religious aspects ofepilepsy in traditional cultures. Epilepsia 1999; 40(3):382-86.

15. Rho JM, Sankar R, Cavazos. JE. Epilepsy: Scientific foundations of clinical practice. New York: Marcel Dekker, 2004.

16. Hertz D, Thurman DJ, Gwinn-Hardy K, Mohamed M, Chaudhury AR, Zalutsky R. How common are the 'Common' neurologic disorders Neurology 2007; 68 (5):326-37.

17. Sridharan R. Epidemiology of epilepsy. Current Science2002; 82(6):664-70.
18. Hanna NJ, Black M, Sander J W et al. The national sentinel audit of epilepsy related death. The Stationary Office, London. 2002:1135.

19. Marieb EN. Human anatomy and physiology. New Delhi Pearson Education Inc and Dorling Kindersley Publishing Inc, 6th ed. 2006:430-88.

20. Frucht MM, Quigg M, Schwaner C, Fountain NB. Distribution of seizure precipitants among epilepsy syndromes. Epilepsia 2000; 41(12):1534-39.

21. Herzog AG, Harden CL, Liporace J, Pennell P, Schomer DL, SperlingM. Frequency of catamenial seizure exacerbation in women with localization-related epilepsy. Annals Neurology 2004; 56(3):431-34.

22. Lowenstein DH. Seizures and epilepsy. In: Kasper DL, Braunwald E, Fauci AS, Hauser SL, Longo DL, Jameson JL, 16th ed Vol. 2. Harrison's principles of internal medicine. USA: McGraw-Hill Companies Inc, 2005:2357-72.

23. Meisler MH, Kearney JA. Sodium channel mutations in epilepsy and other neurological disorders. Journal of Clinical Investigation 2005; 115(8):2010-17

24.Commission on classification and Terminology of the International League Against Epilepsy. Proposal for revised clinical and electroencephalographic classification of epileptic seizures. Epilepsia 1981; 22: 489-01.

25. Commission on Classification and Terminology of the International League against Epilepsy. Proposal for revised classification of epilepsies and epileptic syndromes. Epilepsia 1989; 30:389-99.

26. Porter RJ, Meldrum BS. Antiseizure drugs. In: Katzung BG, ed Basic and clinical pharmacology. New York: Mc Graw-Hill Companies Inc, 10th edition. 2006: 378.

27. Rang HP, Dale MM, Ritter JM, Moore PK. Pharmacology. New Delhi: Churchill Livingstone Reed Elsevier India (P) Ltd, 5th ed. 2006:550-60

28. Tripathi KD. Essential of medical pharmacology. New Delhi: Jaypee Brothers Medical publishers (P) Ltd, 5th ed. 2003:36980.

29. Guyton AC, Hall JE. Text book of medical physiology.; Elsevier a division of Reed Elsevier India (P) Ltd, 11th ed. 2007:743-47.

30. Sweetman S C. Martindale the complete drug reference. London: Pharmaceutical Press, 33rd ed. 2002:338-69.

31.Wolf P of Cabbages and kings: Some consideration on classifications, diagnostic schemes, semiology and concepts. Epilepsia. 2003; 44(1): 1-4.

32.Block JH, Beale JM. Wilson and Gisvold's text book of organic medicinal and pharmaceutical chemistry. 11th ed. Lippincott Williams and Wilkins, 2010:503.

33.Bennett PN, Brown MJ. Clinical pharmacology. New Delhi: Elsevier a division of Reed Elsevier India (P) Ltd, 9th ed. 2006: 413-22.

34.Rall TW, Schleifer LS. Drugs effective in the therapy of the epilepsies. In: Goodman Gilman A, Goodman LS, Rall TW, Murad F, eds. Goodman \& Gilman's the pharmacological basis of therapeutics. New York: Macmillan Publishing Company, 7th ed. 1985: 446-72. 